\title{
Defensive responses and palatability of specialist herbivores: predation on NE Pacific ascoglossan gastropods
}

\author{
Cynthia D. Trowbridge* \\ Department of Biology, Syracuse University, Syracuse, New York 13244, USA \\ and \\ Oregon Institute of Marine Biology, Charleston, Oregon 97420, USA
}

\begin{abstract}
Four common species of temperate NE Pacific ascoglossan (= sacoglossan) sea slugs were examined in 1990 and 1991 to determine the nature and effectiveness of their defensive responses and the potential ecological importance of predation. The 3 small, cryptic species (Placida dendritica, Stiliger fuscovittatus, Alderia modesta) responded to mechanical stimulation by waving and autotomizing cerata (finger-like projections on dorsal surfaces), secreting viscous white fluid, and reducing body surface $\mathrm{pH}$. These responses, however, were ineffective deterrents against common intertidal predatory fishes and crabs: the predators readily consumed the cryptic herbivores in short-term laboratory experiments. Furthermore, predators significantly reduced densities of A. modesta on algal mats of Vaucheria sp. in a $12 \mathrm{~d}$ field experiment conducted in Yaquina Bay, Oregon, USA. Thus, small, cryptic ascoglossans were subject to intense predation pressure. In contrast, the large, conspicuous Aplysiopsis enteromorphae had more intense defensive responses (e.g. ejection of viscous fluid, acidic secretions), and few predators consumed the ascoglossan.
\end{abstract}

KEY WORDS: Specialist herbivores · Anti-predator defences · Ascoglossa - Opisthobranchia - Temperate shores

\section{INTRODUCTION}

Plants are attacked by a diverse assemblage of herbivores. In many terrestrial communities, specialist herbivores are abundant and diverse (Root 1973, Bernays 1989). In contrast, marine herbivores are primarily generalist feeders with relatively few specialists (Lubchenco \& Gaines 1981, Hay et al. 1989, 1990a, b). Most of the described species of known marine specialist herbivores are ascoglossan sea slugs (Gastropoda: Opisthobranchia) - small suctorial herbivores.

Predation has been implicated frequently in selecting for herbivore specialization (e.g. Bernays \& Graham 1988, Hay et al. 1989, 1990a, b) though evidence

\footnotetext{
- Present address: Hatfield Marine Science Center, Oregon State University, Newport, Oregon 97365, USA
}

is mixed (Bernays 1989, Stamp 1992). There are at least 4 gaps in our understanding of whether predation selects for narrow host-plant range and diet in marine herbivores. (1) Although populations of small marine crustaceans are often limited by predators, comparable information for the stenophagous ascoglossan opisthobranchs is lacking. (2) Despite numerous studies on potential mechanisms of opisthobranchs to avoid or deter predation (e.g. crypsis, autotomy, reduction of $\mathrm{pH}$, secretion of sequestered or synthesized secondary metabolites), the effectiveness of the defenses against different predators has often been assumed rather than tested (out see Thompson 1960a, b, Jensen 1984, Paul \& Van Alstyne 1988, Hay et al. 1989, 1990a, b, McClintock et al. 1991). (3) Critical evidence often lacking is that intraspecific variation in host-plant use and/or diet directly affects herbivore survival (see Pennings 1990 for notable 
exception). (4) Past work on interactions of marine predators and specialist herbivores focuses on tropical to warm-temperate species (e.g. Lewin 1970, Jensen 1984, Paul \& Van Alstyne 1988, Hay et al 1989, 1990b, Pennings 1990. Roussis et al. 1990) with little comparable work on their cold-water counterparts.

In this paper, I address these points by examining 4 species of small, stenophagous, ascoglossan sea slugs common in marine and estuarine intertidal areas along the central coast of Oregon, USA. My objectives are (1) to document the responses of ascoglossans to simulated predator attacks, (2) to determine whether cryptic ascoglossans are more palatable to predators than are conspicuous species, and (3) to determine whether predators significantly reduce slug densities.

\section{NATURAL HISTORY}

Placida dendritica (Alder \& Hancock) inhabits temperate to boreal coastal waters throughout the world and feeds selectively on the green algae Codium spp. and Bryopsis spp. throughout its geographic range (Trowbridge 1992). Along the Oregon coast, $P$. dendritica associates with 3 species of low intertidal algae: $C$. setchellii, C. fragile, and B. corticulans (Trowbridge $1991 \mathrm{a}, \mathrm{b}, 1992,1993 \mathrm{~b})$. The slug is small, attaining lengths of ca $5 \mathrm{~mm}$ on Codium spp. and ca $15 \mathrm{~mm}$ on $B$. corticulans. P. dendritica is visually cryptic on the algal hosts: (1) the retention of ingested algal chloroplasts makes the herbivore match the color of the algal host and (2) the ascoglossan's cerata look like Codium spp. utricles and $B$. corticulans branches.
Stiliger fuscovittatus Lance is a NE Pacific species that associates with the red algae Callithamnion sp. and Polysiphonia sp. in marine and estuarine areas (Lance 1962, Millen 1980, 1989, Morris et al. 1980, author's pers. obs.). S. fuscovittatus is small $(<10 \mathrm{~mm}$ long) and visually cryptic: the body is fairly transparent with some reddish-brown pigmentation (Lance 1962) that camouflages the herbivore on its red algal hosts.

Alderia modesta (Lovén) associates with high intertidal, yellow-green algal mats (Vaucheria spp.) in temperate and boreal estuaries in the northern hemisphere (Trowbridge 1993c). Maximum A. modesta length in Oregon is ca $6 \mathrm{~mm}$ (Trowbridge 1993c, d). Dorsal body surfaces are green to olive, rendering A. modesta visually cryptic on the algal mats.

Aplysiopsis enteromorphae (Cockerell \& Eliot) is restricted to the NE Pacific (Trowbridge 1993a, d). The species occurs in open coast, high intertidal pools and on estuarine mud flats in association with filamentous green algae (Gonor 1961a). In Oregon tidepools, the ascoglossan feeds on Chaetomorpha linum and Cladophora columbiana (Trowbridge 1993a, d). Its large size (to $27 \mathrm{~mm}$ ) and black and white pigmentation render $A$. enteromorphae visually conspicuous on its bright green algal hosts (Trowbridge 1993a, d).

Although ascoglossans encounter a diverse assemblage of potential predators, I focused on the most common carnivorous macroinvertebrates and fishes on the Oregon shore (Table 1). These species were all intermediate-sized predators: crabs were $<6 \mathrm{~cm}$ in carapace width, and nemerteans and fishes were 5 to $10 \mathrm{~cm}$ in length.

Table 1. Marine and estuarine predators tested in this study. Values in the 2 right columns indicate the number of replicates in which Aplysiopsis enteromorphae were eaten or not eaten in laboratory feeding experiments. No escapes, mortalities, or counting errors occurred in the 49 no-predator controls conducted

\begin{tabular}{|c|c|c|c|c|c|c|}
\hline Habitat & Potential predators & Scientific names and authorities & $\begin{array}{l}\text { Reported max. } \\
\text { size }(\mathrm{cm})^{\mathrm{a}, \mathrm{b}}\end{array}$ & $\begin{array}{l}\text { Size range } \\
\text { used }(\mathrm{cm})^{d}\end{array}$ & $\begin{array}{l}\text { Slugs } \\
\text { eaten }\end{array}$ & $\begin{array}{l}\text { Slugs not } \\
\text { eaten }\end{array}$ \\
\hline Marine & Tidepool sculpin ${ }^{r}$ & Oligocottus maculosus Girard & 8.9 & $5-9$ & 1 & 11 \\
\hline Marine & Spotfin surfperch ${ }^{\mathrm{C}}$ & Hyperprosopon anale Agassiz & 20.0 & $5-10$ & 0 & 4 \\
\hline Marine & Purple shore crabc & Hemigrapsus nudus (Dana) & 5.6 & $1.3-3.4$ & 0 & 20 \\
\hline Marine & Striped shore $\mathrm{crab}^{\mathrm{d}}$ & Pachygrapsus crassipes Randall & 4.8 & $1.4-2.1$ & 0 & 5 \\
\hline Marine & Nemertean ${ }^{\mathrm{e}}$ & Amphiporus sp. & - & $5-10$ & 0 & 5 \\
\hline Estuarine & Staghorn sculpin' & Leptocottus amatus Girard & 46.0 & $5-10$ & 0 & 14 \\
\hline Estuarine & Shiner surfperch: & Cymatogaster aggregata Gibbons & 18.0 & $5-7$ & 0 & 5 \\
\hline Estuarine & Purple shore crab & Hemigrapsus nudus (Dana) & 5.6 & $2.2-5.6$ & 0 & 12 \\
\hline Estuarine & Mud-flat crabt & Hemigrapsus oregonensis (Dana) & 3.5 & $1.5-2.4$ & 2 & 8 \\
\hline \multirow[t]{3}{*}{ Estuarine } & Dungeness crabg & Cancer magister Dana & 23.0 & $<4.5$ & & \\
\hline & & 2nd instars & & & 0 & 8 \\
\hline & & 5 th instars & & & 4 & 3 \\
\hline \multicolumn{7}{|c|}{${ }^{a}$ Fish and nemertean size measured as length, crab size as carapace width } \\
\hline \multicolumn{7}{|c|}{${ }^{b}$ Morris et al. (1980) and Eschmeyer \& Herald (1983) } \\
\hline \multicolumn{7}{|c|}{ 'Single expt, Jul 1991; 'Single expt, Jul 1991; 'eSingle expt, Aug 1990; 'Separate expts, Sep 1991} \\
\hline \multicolumn{7}{|c|}{ geparate expts, Jun \& Aug 1991} \\
\hline
\end{tabular}




\section{METHODS}

Collection information. During summer 1991, I collected ascoglossans and potential predators at several sites along the central coast of Oregon $\left(43\right.$ to $45^{\circ} \mathrm{N}$, $124^{\circ} \mathrm{W}$ ). The rocky shore, open coast sites (from south to north) were Cape Arago, Strawberry Hill, Seal Rock, and Boiler Bay State Parks. The estuarine sites were Coos Bay and Yaquina Bay. Specimens were brought to the laboratory to quantify defensive responses of the ascoglossans and palatability of herbivores to potential predators.

Defensive responses. I examined (under a dissecting microscope) 20 to 30 ascoglossans for each of the 4 common species. For Aplysiopsis enteromorphae and Placida dendritica, I examined conspecific individuals from each of 2 sympatric algal host species (Chaetomorpha linum and Cladophora columbiana; Codium fragile and Bryopsis corticulans, respectively) to determine whether responses were host-specific. To simulate predator attacks, I squeezed the body of each ascoglossan 10 times with fine forceps, mimicking prey handling by small- to intermediate-sized predators [e.g. pinching by sea spiders (Piel 1991) and crabs (author's pers. obs.), cerata nipping by small fishes]. The fact that the observed responses were qualitatively similar to those reported for a diversity of opisthobranch and pulmonate molluscs suggests that the mechanical stimulation did reasonably simulate predator attacks.

I noted the presence or absence of 3 types of responses: (1) waving cerata (finger-like projections on dorsal surfaces), (2) autotomizing cerata, and (3) secretion of viscous, white fluid. For (3), I noted whether the secretions were weak and oozing or strong ejections. I used G-tests and Fisher's exact tests (depending on sample size) to compare the frequency of responses among species (Sokal \& Rohlf 1981). Because all these responses are commonly considered defensive and presumed to deter predators, I refer to them as defensive responses. The effectiveness of the responses against common intermediate-sized predators is evaluated in a later section

I also quantified the body surface $\mathrm{pH}$ of ascoglossans to determine whether acidic substances were secreted, comparable to those of nudibranchs and many other gastropods. I gently placed individual Aplysiopsis enteromorphae from Cladophora columbiana and Chaetomorpha linum on a paper towel to remove seawater and then on $\mathrm{pH}$ paper to record the $\mathrm{pH}$ value. Then I squeezed new individuals of $A$. enteromorphae 10 times each with fine forceps and recorded the resulting $\mathrm{pH}$ ( $\mathrm{n}=10$ to 11 slugs per host species). The procedure was repeated with Placida dendritica, Stiliger fuscovittatus, and Alderia modesta. Replication was 10 to 20 individuals per species and samples per seawater control. I tested whether $\mathrm{pH}$ differed with respect to ascoglossan species, disturbance, or algal diet.

Palatability experiments. General procedures: From May to September 1991, I conducted a series of shortterm feeding experiments to determine which predators would consume ascoglossans. To acclimate predators to the laboratory, fishes and crabs were held in a running-seawater table for approximately $2 \mathrm{~d}$. To feed the predators, red algal turfs (Neorhodomela larix, Odonthalia flocossa) containing rich assemblages of amphipods, isopods and small snails were set into the seawater table daily.

For each experiment, I placed ascoglossans in $1.2 \mathrm{I}$ plastic containers (with Nitex mesh sides) with predators for short periods ( 0.5 to $3 \mathrm{~d}$ ) to examine whether the predators would readily consume potential prey. Unless otherwise noted, ascoglossan densities were 5 Placida dendritica, 10 Stiliger fuscovittatus , 10 Alderia modesta, or 1 Aplysiopsis enteromorphae per container. Typically, 1 predator was added to each experimental container, except for small predators, where 2 to 5 were used. Although the duration of trials and the starting densities of ascoglossans and predators varied among experiments, the critical point was whether predators consumed ascoglossans, not the extent of predation. Control treatments without predators were included to quantify counting errors, slug escapes, and mortalities. At the end of each experiment, I counted the slugs remaining in the presence and absence of predators. Because data were usually not normally distributed (even with transformations), I used non-parametric analyses (Kruskal-Wallis or Mann-Whitney $U$-tests) for most experiments (Zar 1984).

Diversity of predators: I tested whether cryptic ascoglossans would be eaten by common sympatric predators (i.e. not all predator by prey combinations). Placida dendritica, collected from the green alga Codium setchellii, was offered to individual tidepool sculpins, spotfin surfperch, and purple shore crabs in a single experiment. Stiliger fuscovittatus was offered to 3 species of marine and estuarine fishes (tidepool sculpins, staghorn sculpins, shiner surfperch) in separate experiments. Finally, Alderia modesta was offered to 5 species of estuarine predators: staghorn sculpins, shiner surfperch, mud-flat crabs, purple shore crabs, and Dungeness crabs. Separate experiments were conducted for each of the following stages of Dungeness crabs: 2nd instars (5 container ${ }^{-1}$ ), 3rd instars (2 containe ${ }^{-1}$ ), and 5 th instars ( 1 container $^{-1}$ ). Replication varied from 4 to 20 samples per treatment, depending on slug and predator availability.

To determine whether Aplysiopsis enteromorphae was palatable, I tested 5 marine predators: tidepool 
sculpins, spotfin surfperch, purple and striped shore crabs, and nemerteans. I also tested 5 species of estuarine predators: staghorn sculpins, shiner surfperch, purple shore crabs, mud-flat crabs, and Dungeness crabs (2nd and 5th instars as described above). Replication varied from 4 to 20 samples per treatment in each experiment.

Algal diets: Because Placida dendritica and Aplysiopsis enteromorphae vary widely in body length and each inhabit 2 sympatric species of green algae (Trowbridge 1992, 1993a, c), slug size or algal diet may influence predation. To determine whether $P$. dendritica from different host species were equally palatable to predators, I offered 1 ascoglossan from either Codium setchellii or Bryopsis corticulans to individual tidepool sculpins ( $n=6$ replicate fish per algal host). After $15 \mathrm{~h}$, I counted the fish that consumed $P$. dendritica. I placed individual $A$. enteromorphae from Cladophora columbiana $(\mathrm{n}=7)$ or Chaetomorpha linum $(\mathrm{n}=8)$ in containers with single tidepool sculpins and recorded which slugs remained after $1 \mathrm{~d}$. I tested whether eaten or uneaten slugs varied in length and whether sculpins exhibited a preference between slugs from different host species.

Predation in situ. Predator exclusion experiment: To determine if estuarine predators significantly reduced densities of Alderia modesta in the field, I conducted a 12 d experiment in August 1990, excluding predators from foraging over Vaucheria sp. algal mats directly below the salt marsh in Yaquina Bay. I used cages $(25 \times 25 \times 25 \mathrm{~cm})$ constructed of steel hardware cloth (mesh opening $6 \mathrm{~mm}$ ). The 4 treatments were: total exclusion (full cage), 2 cage controls ( 2 sides and a top; 4 sides and no top), and unmanipulated control (no cage). Each treatment had 6 replicate caged or uncaged areas of Vaucheria sp. mat. I placed the treatments at randomly determined locations, along a $100 \mathrm{~m}$ stretch of Vaucheria sp. To prevent predators from burrowing under the cages, I pushed each cage $5 \mathrm{~cm}$ into the mud. For $12 \mathrm{~d}$, I monitored the cages daily as the mats were exposed by the ebbing tide. I counted $A$. modesta in each cage and unmanipulated control area. After checking that homogeneity of variance and normality of data assumptions were valid, I compared the treatment means at the start of the experiment and at $12 \mathrm{~d}$ with analysis of variance, followed by Student-NewmanKeuls (SNK) tests.

Slug movements: The behavior of herbivores may influence their susceptibility to predators. The numbers of Alderia modesta remaining on the surface of algal mats was checked several times during tidal emergence in 12 randomly selected $0.25 \mathrm{~m}^{2}$ quadrats of Vaucheria sp. mat on 2 consecutive days in June 1990 at Yaquina Bay. Furthermore, the movement of
A. modesta was measured in 5 randomly selected $0.25 \mathrm{~m}^{2}$ quadrats of Vaucheria sp. mat in July 1990. For 10 consecutive days, ascoglossans were counted and removed from each quadrat immediately after the mat emerged on the ebbing tide.

\section{RESULTS}

\section{Defensive responses}

Ascoglossan species. All the ascoglossan species, except Alderia modesta, waved and autotomized cerata when prodded and squeezed (Fig. 1). Although the frequency of both behaviors varied significantly among ascoglossan species ( $G$-test, $G=71.8 \mathrm{df}=3, \mathrm{p}<$ $0.001 ; G=20.9, \mathrm{df}=3, \mathrm{p}=0.001$, respectively), the behaviors did not differ consistently between cryptic and conspicuous species ( $p=0.709$ and $p=0.379$ ). Most ascoglossans (63 to $88 \%$ of each species) released viscous white fluid, but the frequency of secretion did not vary with species $(G=5.0, \mathrm{df}=3, \mathrm{p}=$ 0.211 ) or coloration ( $G=1.2, \mathrm{df}=1, \mathrm{p}=0.271$ ). In contrast, the intensity of secretion did vary significantly between conspicuous and cryptic species (Fisher's exact test, $p=0.001$ ): $23 \%$ of the conspicuous Aplysiopsis enteromorphae curled up and ejected fluid up to 1 body length away whereas all the cryptic ascoglossans had weaker, more localized responses (oozing secretions).

Another response was reduced body surface $\mathrm{pH}$ (Fig. 2A). For example, the mean surface $\mathrm{pH}$ value of undisturbed Aplysiopsis enteromorphae was 7.2; after

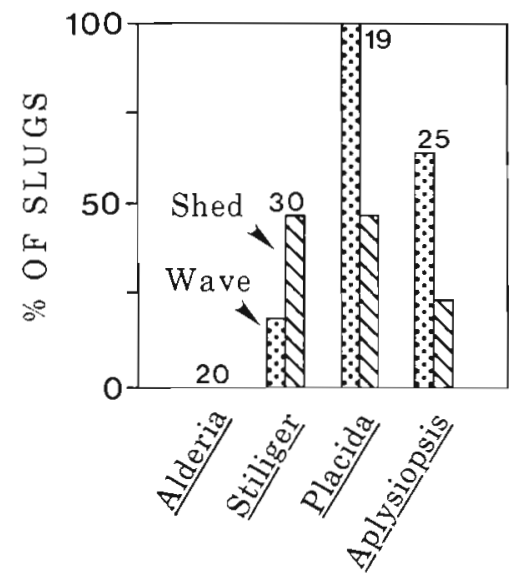

Fig. 1. Alderia modesta, Stiliger fuscovittatus, Placida dendritica, Aplysiopsis enteromorphae. Frequency of ceratal responses of ascoglossan gastropods when prodded and squeezed with fine forceps: waving (wave) and shedding (shed) (= autotomizing) cerata. Values above bars denote the number of individuals examined for each species 
mechanical disturbance, their bodies became acidic $(\bar{X}=4.1)$. The 3 cryptic species (Fig. 2B) had undisturbed $\mathrm{pH}$ values significantly more basic than seawater (Kruskal-Wallis $H=35.5, \mathrm{p}<0.001$; nonparametric SNK, $\mathrm{p}<0.05)$. All 3 species significantly reduced their $\mathrm{pH}$ when disturbed (Wilcoxon signed ranks test, $\mathrm{p}<$ $0.001)$ but were barely, if ever, acidic (Fig. 2B). In fact, the $\mathrm{pH}$ of disturbed Alderia modesta was basic while those of Stiliger fuscovittatus and Placida dendritica were neutral $(H=16.3, p<0.001$; non-parametric SNK, $p<0.05$ ). In contrast to interspecific differences, intraspecific variation was very low (SE values were all $<0.17 \mathrm{pH}$ units).

Algal diet. Defensive responses of Aplysiopsis enteromorphae and Placida dendritica did not generally vary with algal diet (e.g. Fig. 2A) with 3 possible exceptions. A. enteromorphae from Chaetomorpha linum (1) waved cerata significantly more frequently (Fisher's exact test, $n=25, p=0.033$ ) and (2) secreted more intensely $(p=0.005)$ when prodded than did conspecifics collected from Cladophora columbiana. Both results, however, may have been a function of body size rather than of diet since slugs from Chaetomorpha linum were up to twice the size of conspecifics from Cladophora columbiana. (3) Body surface $\mathrm{pH}$ of undisturbed $P$. dendritica was significantly lower for individuals from Bryopsis corticulans $(\bar{X}=7.9)$ than for conspecifics from Codium fragile $(\bar{x}=8.4)$ (Mann-Whitney $U=22.0$, $\mathrm{n}=20, \mathrm{p}=0.006$ ). The $\mathrm{pH}$ of disturbed individuals, however, did not vary with algal diet $(U=46.0, \mathrm{n}=20$, $p=0.768$ ).

\section{Palatability experiments}

Diversity of predators. The small, cryptic marine ascoglossans were readily consumed by common predators. For example, $81 \%$ of the predators ate Placida dendritica. Tidepool sculpins consumed, on average, more $P$. dendritica than did spotfin surfperch or purple shore crabs though the predator treatments did not differ significantly (Fig, 3A, Kruskal-Wallis $H=$ 21.4, $\mathrm{p}<0.001$; non-parametric SNK, $\mathrm{p}>0.05)$. Marine and estuarine predators readily ate Stiliger fuscovittatus (Fig. 3B): tidepool sculpins (Mann-Whitney $U=$ $32.0, p=0.006)$, juvenile staghorn sculpins $(U=32.0$, $\mathrm{p}=0.005)$, and shiner surfperch $(U=6.5, \mathrm{p}=0.005)$. Furthermore, estuarine predators readily consumed Alderia modesta (Fig. 3C): juvenile staghorn sculpins
A. Conspicuous

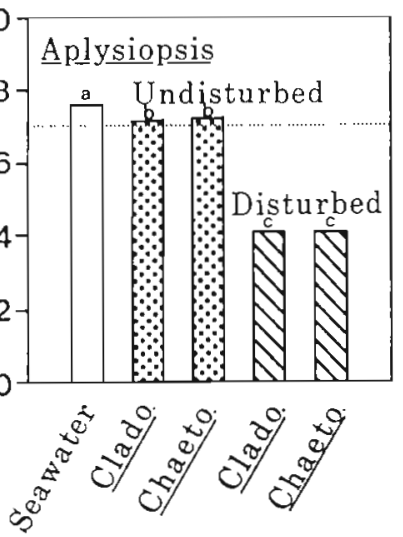

B. Cryptic

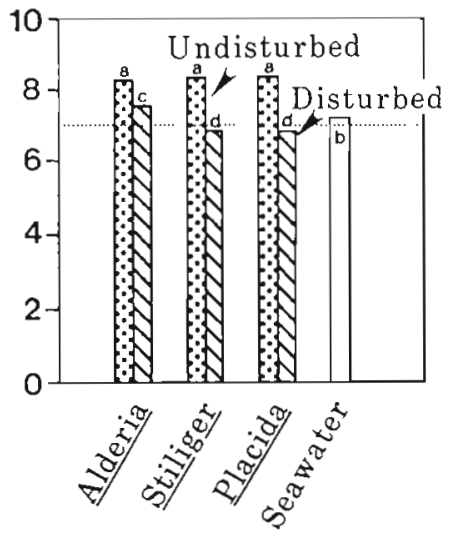

Fig. 2. Surface $\mathrm{pH}$ values of (A) Aplysiopsis enteromorphae, a conspicuous whereas bars with dissimilar letters do vary. Error bars omitted because ze (SE values $<0.17 \mathrm{pH}$ units). Algae - Clado
columbiana; Chaeto.: Chaetomorpha linum

$(U=3.5, \mathrm{p}=0.004)$, juvenile shiner surfperch $(U=2.5$, $\mathrm{p}=0.028)$, mud-flat crabs $(U=2.5, \mathrm{p}<0.001)$, and purple shore crabs $(U=24.0, p=0.001)$. Juvenile Dungeness crabs, however, generally ignored $A$. modesta: 2nd instar crabs $(U=31.5, \mathrm{n}=14, \mathrm{p}=0.142)$, 3rd instars $(U=25.0, \mathrm{n}=17, \mathrm{p}=0.347)$, and 5th instars $(U=18.5$, $\mathrm{n}=16, \mathrm{p}=0.610$ ).

The conspicuous Aplysiopsis enteromorphae was rarely consumed by common marine predators and estuarine fishes (Table 1). Crabs generally ignored $A$. enteromorphae although some estuarine mud-flat crabs and 5th instar Dungeness crabs consumed the ascoglossan (Table 1). Slug densities did not vary significantly in crab and no-crab treatments after 1 or $2 \mathrm{~d}$ (Mann-Whitney $U=40.0, \mathrm{n}=11, \mathrm{p}=0.098 ; U=17.0$, $\mathrm{n}=15, \mathrm{p}=0.151)$. A. enteromorphae seemed unattractive or unpalatable to a suite of marine and estuarine predators.

Algal diet. The algal hosts from which ascoglossans were collected did not influence palatability to fishes. When I offered individual Placida dendritica from Bryopsis corticulans or Codium setchellii to tidepool sculpins, 5 of the 6 fish ( $83 \%$ ) consumed the herbivore in each treatment even though $P$. dendritica from $B$. corticulans were usually much larger than conspecifics from $C$. setchelli. In a comparable experiment with Aplysiopsis enteromorphae, the algal host from which slugs were collected did not influence tidepool sculpin predation (Fisher's exact test, $\mathrm{n}=15, \mathrm{p}=0.569$ ). Slug size also had no significant effect on predation (MannWhitney $U=10.0, \mathrm{n}=15, \mathrm{p}=0.239$ ). 


\section{A. Placida}
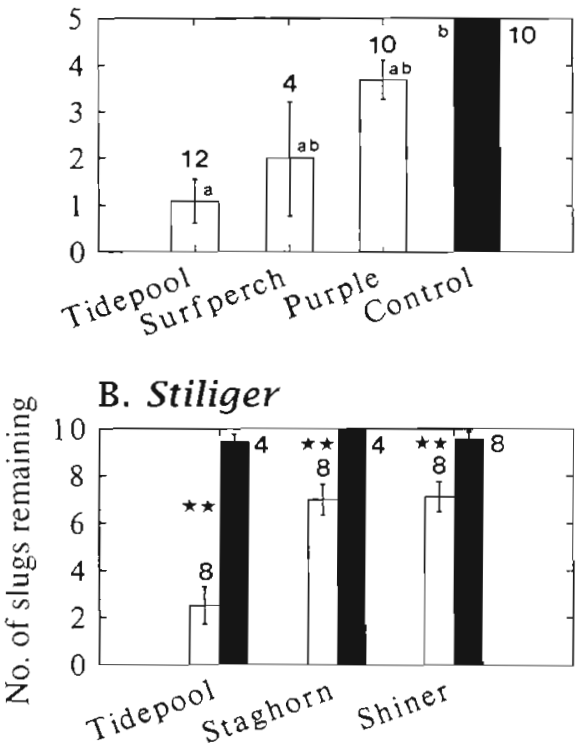

\section{Alderia}

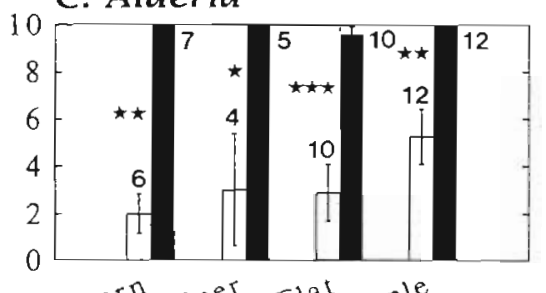

staghorn shiner MudFlat purple

Fig. 3. Predation on cryptic ascoglossans in laboratory experiments. (A) Placida dendritica was collected from Codium setchellii. (B) Predation on Stiliger fuscovittatus in 3 separate experiments. (C) Predation on Alderia modesta in 4 experiments. White bars: predator; black bars: control. Tidepool: tidepool sculpin; surfperch: spotfin surfperch; purple: purple shore crab; staghorn: staghorn sculpin; shiner: shiner surfperch; mud flat: mud-flat crab. Numbers and letters above bars as in Fig. 2. Error bars $= \pm 1 \mathrm{SE}$. When mean values in the controls are $5(\mathrm{~A})$ or $10(\mathrm{~B}, \mathrm{C})$, no slugs were missing from any replicate (i.e. no variation). Asterisks denote the level of statistical significance based on Mann-Whitney $U$-tests: $p<$ $0.05, \cdots p<0.01, \cdots p<0.001$

\section{Predation in situ}

Predator exclusion experiment. The initial density of Alderia modesta $\left(\bar{x}=21.5\right.$ per $\left.625 \mathrm{~cm}^{2}, \mathrm{SE}=3.7\right) \mathrm{did}$ not vary among treatments. After 12 d, however, slug densities (Fig. 4) were significantly greater on Vaucheria sp. mats within predator exclusion cages than in the unmanipulated controls (ANOVA, $F=5.8$, $p=0.005$; SNK, $p<0.005$ ). Manipulation control treatments had intermediate ascoglossan densities. The results were not due to shade effects (e.g. ascoglossans

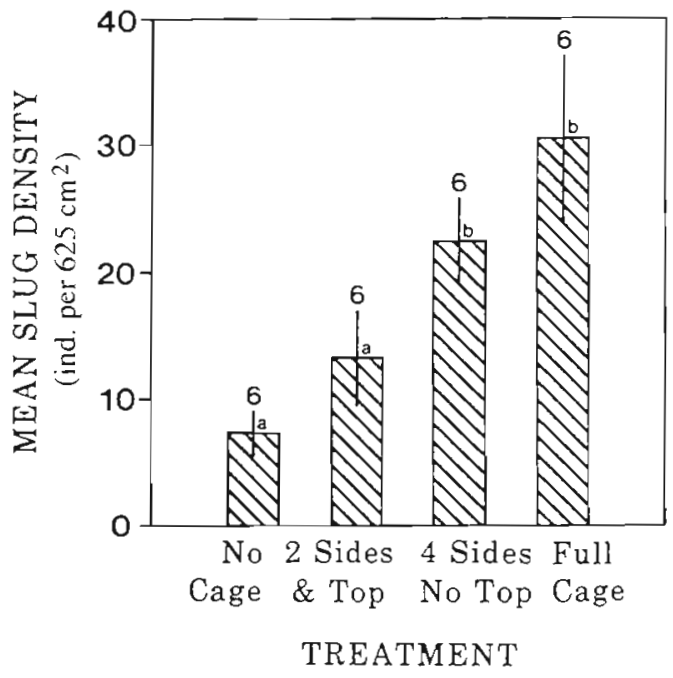

Fig. 4. Alderia modesta. Sea slug densities in the $12 \mathrm{~d}$ predator exclusion experiment conducted in August 1990 in Yaquina Bay, Oregon. Error bars $= \pm 1 \mathrm{SE}$. Numbers and letters above bars as in Fig. 2

attracted to cooler, moister environment inside cages) because the 4 sides/no top control was statistically similar to the total exclusion treatment whereas the 2 sides/top control was similar to the unmanipulated control. Furthermore, the higher densities in the exclusion cages did not reflect ascoglossan predator avoidance. In fact, in the laboratory, A. modesta often crawled on fishes and crabs (before the predators consumed them).

Slug movements. During low tide exposure, many Alderia modesta burrowed into the algal mats, hiding in crevices and small holes. Thus, the density of epifaunal individuals decreased with increased aerial exposure (Fig. 5A). Because some individuals moved continuously (into the mat, then onto the surface), epifaunal slugs were always present, even on days when the algal mats were not submerged by the tide.

Alderia modesta actively moved across the mat surface during submergence (Fig. 5B). During the period of diurnal submergence, the number of recruiting $A$. modesta counted (and removed) ranged from ca 25 to 60 quadrat $^{-1}$ (Day 1 value was density prior to initial removal). During the period of semidiurnal submergence (Days 7 to 10), slug recruitment (and removal) increased to over 125 .

An important aspect of predation pressure on Alderia modesta populations is the extent to which ascoglossans will replace removed conspecifics. In June 1990 (Fig. 5B), the local population rapidly replaced removed slugs. In contrast, in August 1990 (Fig. 4), A. modesta populations declined on Vaucheria $\mathrm{sp}$. mats (except in the predator exclusion cages). 
Fig. 5. Alderia modesta. (A) Sea slugs remaining on the surface of Vaucheria sp. mats during low tide emergence on 2 sequential days in June 1990. (B) Immigration of $A$. modesta during diurnal and semidiurnal submergence. Error bars $= \pm 1 \mathrm{SE} . \mathrm{n}=$ no. of replicate $0.25 \mathrm{~m}^{2}$ quadrats examined
A. Burrowing

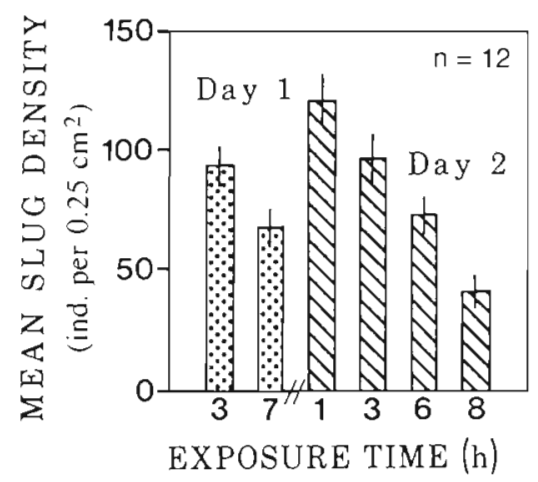

B. Immigration

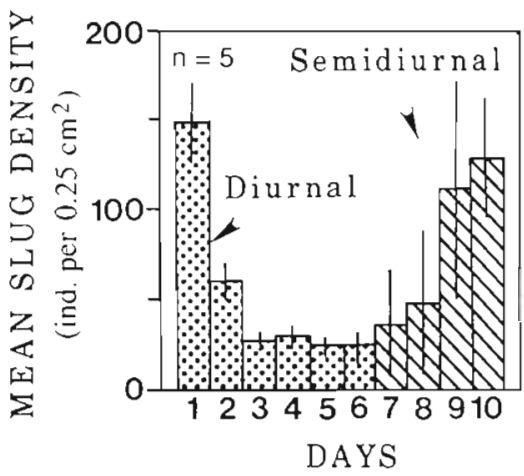

\section{DISCUSSION}

\section{Ascoglossan responses and palatability}

\section{Autotomy}

Small herbivores frequently have an array of mechanisms to deter potential predators. Results of feeding experiments, however, cast doubt on the effectiveness of autotomy of body parts: Placida dendritica and Stiliger fuscovittatus were both eaten despite shedding their cerata. Edmunds (1966) and Stasek (1967) suggested that autotomy of cerata may protect opisthobranchs if predators nip at the cerata. Yet, predators varied in how they handled prey. Fish often ingested entire ascoglossans (Thompson 1960b, Todd 1981, author's pers. obs.j though many intertidal fishes bite food too large to swallow (K. Brookins pers. comm.). In contrast, crabs held ascoglossans with their chelate appendages and slowly inserted the prey into their mouth: thus, crabs 'sampled' and often rejected their prey. On 1 occasion, a 5th instar Dungeness crab consumed the anterior end of 2 ascoglossans and the posterior end of 3 others. Finally, Piel (1991) noted that sea spiders attacked nudibranchs, pinching the prey and consuming detached cerata, not the slugs. Therefore, ceratal autotomy may be effective deterrents against a diversity of small predators (not examined in this study), but ineffective with intermediate-sized and large predators.

\section{Chemical deterrents}

Many marine gastropods secrete acidic substances, particularly when disturbed (Thompson 1960a, b, Edmunds 1968). The unpalatable Aplysiopsis enteromorphae, however, was not as acidic $(\mathrm{pH} \approx 4)$ as many dorid nudibranchs ( $\mathrm{pH} \approx 1$ to 2 ; Edmunds 1968). The effectiveness of acidity against different types of predators is not clear, particularly because few studies have examined an assemblage of 'ecologically relevant (i.e. sympatric) invertebrate and vertebrate predators' (McClintock et al. 1991). In this study, most predators tested avoided $A$. enteromorphae (Table 1), and Todd (1981) observed that 1 species of acid-secreting nudibranch was readily consumed by eider ducks whereas another species was rejected by herring gulls. Finally, many unpalatable opisthobranchs are neutral (Thompson 1960b, Johannes 1963, McClintock et al. 1991).

All 4 ascoglossan species released a white viscous fluid when physically disturbed, similar to that reported for many other gastropods (Fretter \& Graham 1954, Thompson 1960b, Gonor 1961b, Edmunds 1966 , Branch \& Cherry 1985, Rice 1985). Viscous exudations of pulmonates (Branch \& Cherry 1985, Rice 1985) and opisthobranchs (Lewin 1970, Jensen 1984, Young et al. 1986) often deter predators (but see Piel 1991). Fretter \& Graham (1954) reported that such secretions killed small (though unspecified) animals. Whether the viscous secretions of $A$. enteromorphae were the source of its unpalatability was not clear. Because most predators tested did not even approach the ascoglossan, the herbivore rarely secreted in the laboratory. If low concentrations of fluids, however, leached from the herbivore, predators may detect and avoid the unpalatable species.

Some ascoglossans produce detectable odors. For example, Alderia modesta produces a strong, pungent odor (Hand \& Steinberg 1955, author's pers. obs.), and Hermaea bifida smells like hydrogen sulphide (Hecht 1895). Yet, $A$. modesta is readily consumed by fishes and crabs in spite of the odor (equivalent information is not available for $H$. bifida). In contrast, odoriferous secretions by some opisthobranchs are repellent to some large predators (Ajeska \& Nybakken 1991) and lethal to large crustaceans and fish (Johannes 1963).

Finally, sequestration and de novo synthesis of defensive compounds have been demonstrated in several species of tropical ascoglossans (Paul \& Van Alstyne 1988, Hay et al. 1989, 1990b, Roussis et al. 1990). The extent to which these 2 types of chemical 
defense vary latitudinally in carnivores, herbivores, and sessile prey is not well known (but see Bakus 1974 , Bakus \& Green 1974, McClintock et al. 1991 for discussion of geographic patterns). Sequestration by temperate and boreal herbivores may be lower than in tropical species because of the relative scarcity of secondary compounds in seaweeds (Van Alstyne \& Paul 1990), particularly green algae. Although several families of red and brown algae have secondary metabolites, few temperate and boreal ascoglossans specialize on these host plants. In fact, the unpalatable Aplysiopsis enteromorphae consumes filamentous green algae (Chaetomorpha linum and Cladophora columbiana) that are high preference foods of many generalist herbivores (J. Lubchenco unpubl. data) and, thus, presumably contain few, if any, secondary metabolites. Therefore, $A$. enteromorphae probably synthesizes its own unpalatable compounds.

\section{Coloration}

A pertinent, though unresolved, question is whether visually conspicuous opisthobranchs are aposematic and, consequently, experience less predation than visually cryptic species. Edmunds (1991) concluded that while many boldly colored nudibranchs were unpalatable, little direct evidence demonstrates that bold coloration was the cause of avoidance by predators. Extremely few ascoglossans are boldly colored (but see Roussis et al. 1990) though many species are visually conspicuous against their algal hosts (Trowbridge 1993a, d). Based on the few species for which information is available, boldly colored and conspicuous ascoglossans are unpalatable to predators.

Unless ( 1 ) such coloration is very effective at reducing predation and (2) most predators are visual foragers, prey should be both cryptic and unpalatable. Most ascoglossans are cryptic (either by ingesting and retaining algal chloroplasts or by the presence of camouflaging pigments). Furthermore, 2 large cryptic ascoglossans on temperate shores are unpalatable (Elysia viridis, Thompson 1960b; E. hedgpethi, author's pers. obs.). Many cryptic nudibranchs are unpalatable as well (Thompson 1960b). Yet, the 3 cryptic ascoglossans in this study were palatable. Perhaps there is a large cost associated with unpalatability, particularly in small, short-lived animals such as Placida dendritica, Stiliger fuscovittatus and Alderia modesta.

\section{Predation in situ}

Results of the palatability experiments suggested that predation pressure on small, cryptic ascoglossans would be intense. In fact, in the $12 \mathrm{~d}$ field experiment, densities of Alderia modesta were significantly higher in the predator exclusion cages than in the unmanipulated controls (Fig. 4). Fishes and/or crabs were probably the major predators for 3 reasons. (1) Cage controls would not easily permit the entry and feeding of most of the large, resident shorebirds. Furthermore, the experiment was conducted in early August before fall migration began, and small shorebirds were not observed at the study site during the experiment. (2) A. modesta burrowed into the algal mats during low tide exposure (Fig. 5A), consequently reducing its susceptibility to avian predators. (3) Fishes and shore crabs readily consumed slugs in the laboratory (Fig. $3 \mathrm{C}$ ).

Although the conditions under which predation pressure reduced ascoglossan populations in situ were not examined in detail, considerable temporal and spatial variation was observed. In the June Alderiaremoval experiment, the local population rapidly replaced removed conspecifics, suggesting that smallscale predation effects were minimal. In the August predator-exclusion experiment, however, the local population could not rapidly replace missing slugs. Thus, predation pressure was intense during late summer when juvenile staghorn sculpins and shiner surfperch were abundant (Bayer 1979, Myers 1980). Local and regional differences in ascoglossan populations may also reflect differences in the species composition and abundance of the predator assemblage: Alderia modesta densities were higher in Oregon estuaries where mud-flat and purple shore crabs were not abundant than in northern California where crabs and shorebirds were often common (Trowbridge 1993c).

Because of the paucity of field-based studies examining the role of predation on opisthobranch populations, we have little understanding of how general the observed patterns of predator-herbivore-algal interactions are. Association with and sequestration of secondary metabolites from algal hosts are predator avoidance and deterrence mechanisms of many tropical ascoglossans (Paul \& Van Alstyne 1988, Hay et al. $1989,1990 b)$. De novo synthesis of defensive compounds occurs in tropical and perhaps temperate species (Roussis et al. 1990, this study). Yet, others such as the temperate cryptic species studied herein were palatable, and predators may of ten reduce their densities in situ. Since the majority of 200 or so species of ascoglossans are stenophagous feeders and since their complex interactions with predators and algal hosts vary, predation may not be the sole factor selecting for trophic specialization. Geographic comparisons of unpalatable and palatable specialist herbivores associated with chemically defended and undefended hosts should provide insight as to the generality of the role of predation in selecting for herbivore diet specificity and narrow host-plant range. 
Acknowledgements. I thank J. Leonard, J. Lubchenco, D. Padilla and L. Harris for prompting me to examine predation on ascoglossans; S. Rumrill, C. Brown, H. Ross, and C. B. Trowbridge for advice and assistance during the project; $\mathrm{L}$. Shapiro and L. Weber for use of facilities at the Oregon Institute of Marine Biology and Hatfield Marine Science Center T Turner, T Farrell, M. Hixon, S. Yamada, W. Ballantine, R. Taylor, S. Hooker, and 2 anonymous reviewers made valuable comments on drafts of this paper. The research was supported in part by the Department of Biology, Syracuse University and Department of Zoology, Oregon State University. The writing of the manuscript was supported by National Science Foundation grant BSR-9024399 to J. Lubchenco and grant INT9202846 to C.D.T.

\section{LITERATURE CITED}

Ajeska, R. A., Nybakken, J. (1991). Contributions to the biology of Melibe leonina (Gould, 1852) (Mollusca: Opisthobranchia). Veliger 19: 19-26

Bakus, G. J. (1974). Toxicity in holothurians: a geographic pattern. Biotropica 6: 229-236

Bakus, G. J., Green, G. (1974). Toxicity in sponges and holothurians: a geographic pattern. Science 185: 951-953

Bayer, R. D. (1979). Intertidal shallow-water fishes and selected macroinvertebrates in the Yaquina estuary, Oregon. Hatfield Marine Science Center Guin Library, Newport, OR

Bernays, E. A. (1989). Host range in phytophagous insects: the potential role of generalist predators. Evol. Ecol. 3: 299-311

Bernays, E. A., Graham, M. (1988). On the evolution of host specificity in phytophagous arthropods. Ecology 69: $886-892$

Branch, G. M., Cherry, M. I. (1985). Activity rhythms of the pulmonate limpet Siphonaria capensis Q. \& G. as an adaptation to osmotic stress, predation and wave action. J. exp. mar. Biol. Ecol. 87: 153-168

Edmunds, M. (1966). Defensive adaptations of Stiliger vanellus Marcus, with a discussion on the evolution of 'nudibranch' molluscs. Proc. malac. Soc. Lond. 37: 73-81

Edmunds, M. (1968) Acid secretions in some species of Doridacea (Mollusca, Nudibranchia). Proc. malac. Soc. Lond. 38: $121-133$

Edmunds, M. (1991). Does warning coloration occur in nudibranchs? Malacologia 32: 241-255

Eschmeyer, W. N., Herald, E. S. (1983). A field guide to Pacific coast fishes of North America from the Gulf of Alaska to Baja California. Houghton Mifflin Co., Boston

Fretter, V., Graham, A. (1954). Observations on the opisthobranch mollusc Acteon tornatilis (L.). J. mar. biol. Ass. U.K 33: $565-583$

Gonor, J. J. (1961a). Observations on the biology of Hermaeina smithi, a sacoglossan opisthobranch from the west coast of North America. Veliger 4: 85-98

Gonor, J. J. (1961b). Observations on the biology of Lobiger serradifalci, a shelled sacoglossan opisthobranch from the Mediterranean. Vie Milieu 12: 381-403

Hand, C., Steinberg, J. (1955). On the occurrence of the nudibranch Alderia modesta (Lovén, 1844) on the central Californian coast. Nautilus 69: 22-28

Hay, M. E., Duffy, J. E., Fenical, W. (1990a). Host-plant specialization decreases predation on a marine amphipod: an herbivore in plant's clothing. Ecology 71: 733-743

Hay, M. E., Duffy, J. E., Paul, V. J., Renaud, P. E., Fenical, W. (1990b). Specialist herbivores reduce their susceptibility to predation by feeding on the chemically defended seaweed Avrainvillea longicaulis. Limnol. Oceanogr. 55: $1734-1743$

Hay, M. E., Pawlik, J. R., Duffy, J. E., Fenical, W. (1989) Seaweed-herbivore-predator interactions: host-plant specialization reduces predation on small herbivores. Oecologia $81: 418-427$

Hecht, E. (1895). Contribution à l'étude des nudibranches Mém. Soc. zool. Fr. 8: 539-711

Jensen, K. R. (1984). Defensive behavior and toxicity of ascoglossan opisthobranch Mourgona germaineae Marcus. J. chem. Ecol. 10: 475-486

Johannes, R. E. (1963). A poison-secreting nudibranch (Mollusca: Opisthobranchia). Veliger 5: 104-105

Lance, J. R. (1962). A new Stiliger and a new Corambella (Mollusca: Opisthobranchia) from the northwestern Pacific. Veliger 5: 33-38

Lewin, R. A. (1970). Toxin secretion and tail autotomy by irritated Oxynoe panamensis (Opisthobranchiata; Sacoglossa). Pacif. Sci. 24: 356-358

Lubchenco, J., Gaines, S. D. (1981). A unified approach to marine plant-herbivore interactions. I. Populations and communities. A. Rev. Ecol. Syst. 12: 405-437

McClintock, J. B., Slattery, M., Heine, J., Weston, J. (1991) Chemical defense, biochemical composition and energy content of three shallow-water Antarctic gastropods. Polar Biol. 11: 623-636

Millen, S. V. (1980). Range extensions, new distribution sites, and notes on the biology of sacoglossan opisthobranchs (Mollusca: Gastropoda) in British Columbia. Can. J. Zool. 58: $1207-1209$

Millen, S. V. (1989). Opisthobranch range extensions in Alaska with the first records of Cuthona viridis (Forbes, 1840 ) from the Pacific. Veliger 32: 64-68

Morris, R. H., Abbott, D. P., Haderlie, E. C. (1980). Intertidal invertebrates of California. Stanford University Press, Stanford

Myers, K. W. W. (1980). An investigation of the utilization of four study areas in Yaquina Bay, Oregon, by hatchery and wild juvenile salmonids. M.Sc. thesis, Oregon State Univ. Corvallis

Paul, V. J., Van Alstyne, K. L. (1988). Use of ingested algal diterpenoids by Elysia halimedae Macnae (Opisthobranchia: Ascoglossa) as antipredator defenses. J. exp mar. Biol. Ecol. 119: 15-29

Pennings, S. C. (1990). Multiple factors promoting narrow host range in the sea hare, Aplysia californica. Oecologia 82: $192-200$

Piel, W. H. (1991). Pycnogonid predation on nudibranchs and ceratal autotomy. Veliger 34: 366-367

Rice, S. H. (1985). An anti-predator chemical defense of the marine pulmonate gastropod Trimusculus reticulatus (Sowerby). J. exp. mar. Biol. Ecol. 93: 83-89

Root, R. B. (1973). Organization of a plant-arthropod association in simple and diverse habitats: the fauna of collards (Brassica oleracea). Ecol. Monogr. 43: 95-124

Roussis, V., Pawlik, J. R., Hay, M. E., Fenical, W. (1990). Secondary metabolites of the chemically rich ascoglossan Cyerce nigricans. Experientia 46: 327-329

Sokal, R. R., Rohlf, F. J. (1981). Biometry. The principles and practice of statistics in biological research, 2nd edn. W. H. Freeman \& Co., New York

Stamp, N. E. (1992). Relative susceptibility to predation of two species of caterpillar on plantain. Oecologia 92 $124-129$

Stasek, C. R. (1967). Autotomy in the mollusca. Occas. Pap Calif. Acad. Sci. 61: 1-44 
Thompson, T E. (1960a). Defensive acid-secretion in marine gastropods. J. mar. biol. Ass. U.K. 39: 115-122

Thompson, T. E. (1960b). Defensive adaptations in opisthobranchs. J. mar biol. Ass. U.K. 39: 123-134

Todd, C. D. (1981). The ecology of nudibranch molluscs. Oceanogr. mar. Biol. A. Rev. 19: 141-234

Trowbridge, C. D. (1991a). Diet specialization limits herbivorous sea slug's capacity to switch among food species. Ecology 72: 1880-1888

Trowbridge, C. D. (1991b). Group membership facilitates feeding of the herbivorous sea slug Placida dendritica. Ecology 72: 2193-2203

Trowbridge, C. D. (1992). Phenology and demography of a marine specialist herbivore: Placida dendritica (Gastropoda: Opisthobranchia) on the central coast of Oregon. Mar. Biol. 114: 443-452

Trowbridge, C. D. (1993a). Feeding ecology of the ascoglossan opisthobranch Aplysiopsis enteromorphae (Cockerell \& Eliot): patterns of distribution and impact on tidepooldwelling green algae. J. exp. mar. Biol. Ecol. 169: 233-257

This article was submitted to the editor
Trowbridge, C. D. (1993b). Interactions between an ascoglossan sea slug and its green algal host: branch loss and role of epiphytes. Mar. Ecol. Prog. Ser. 101: 263-272

Trowbridge, C. D. (1993c). Local and regional abundance patterns of the ascoglossan (= sacoglossan) opisthobranch Alderia modesta (Lovén, 1844) in the Northeastern Pacific. Veliger 36: 303-310

Trowbridge, C. D. (1993d). Population structure of two common species of ascoglossan (= sacoglossan) opisthobranchs on the central coast of Oregon, USA. Veliger 36 : $99-106$

Van Alstyne, K. L., Paul, V. J. (1990). The biogeography of polyphenolic compounds in marine macroalgae: temperate brown algal defenses deter feeding by tropical herbivorous fishes. Oecologia 84: 158-163

Young, C. M., Greenwood, P. G., Powell, C. J. (1986). The ecological role of defensive secretions in the intertidal pulmonate Onchidella borealis. Biol. Bull. 171: 391-404

Zar, J. H. (1984). Biostatistical analysis, 2nd edn. PrenticeHall, Inc., Englewood Cliffs

Manuscript first received: August 3, 1993

Revised version accepted: December 1, 1993 